\title{
Total recovery of resources and energy from rice straw using microwave-induced pyrolysis
}

\author{
Y.F. Huang ${ }^{\text {a }}$, W.H. Kuan ${ }^{\text {b }}$, S.L. Lo ${ }^{\mathrm{a}, *}$, C.F. Lin ${ }^{\mathrm{a}}$ \\ ${ }^{a}$ Graduate Institute of Environmental Engineering, National Taiwan University, 71, Chou-Shan Road, Taipei 106, Taiwan, ROC \\ ${ }^{\mathrm{b}}$ Department of Safety, Health and Environmental Engineering, Mingchi University of Technology, 84, Gung-Juan Road, Taishan, Taipei 243, Taiwan, ROC
}

\section{A R T I C L E I N F O}

\section{Article history:}

Received 14 November 2007

Received in revised form 4 March 2008

Accepted 5 March 2008

Available online 28 April 2008

\section{Keywords:}

Total recovery

Rice straw

Microwave-induced pyrolysis

\begin{abstract}
A B S T R A C T
This article presents the application of microwave-induced pyrolysis to total recovery of resources and energy from rice straw. The microwave power and particle size of feedstock were both key parameters affecting the performance of microwave-induced pyrolysis. Under $400-500 \mathrm{~W}$ microwave power, the reduction of fixed carbon in the biomass was significant. From the experimental results of specific surface area, zeta potential, and $\mathrm{Cu}^{2+}$ adsorption, the applications of solid residues in the water and wastewater treatment could be expected. The major compositions in gaseous product were $\mathrm{H}_{2}, \mathrm{CO}_{2}, \mathrm{CO}, \mathrm{CH}_{4}$ of 55,17 , 13,10 vol.\%, respectively. The high $\mathrm{H}_{2}$ content might imply that microwave-induced pyrolysis of biomass waste has the potential to produce the $\mathrm{H}_{2}$-rich fuel gas. Alkanes, polars, and low-ringed polycyclic aromatic hydrocarbons were three primary kinds of compounds in the liquid product.
\end{abstract}

(c) 2008 Elsevier Ltd. All rights reserved.

\section{Introduction}

Biomass waste was not properly disposed in the past, but now there is a growing trend to account it as a source of resources and energy. Biomass is a mixture of hemicellulose, cellulose, lignin and minor amounts of other organics which each pyrolyze or degrade at different rates and by different mechanisms and pathways (Bridgwater et al., 1999). Wood, crops, and agricultural and forestry residues are some of the main renewable energy resources available, besides, the biodegradable components of municipal solid waste (MSW) and commercial and industrial wastes are also significant bioenergy resources (Bridgwater, 2006). In the past, many of the agricultural and forestry residues and MSW are directly incinerated, but the $\mathrm{CO}_{2}$ emission problem needs to be further concerned. For the purpose of more resources and energy recovery and less $\mathrm{CO}_{2}$ emission, there are many alternative technologies that include thermal, biological, and other treatments. Thermal treatments except incineration mainly contain carbonization, pyrolysis, and gasification. The older literature generally equates pyrolysis to carbonization, in which the principal product is a solid char. Today, the term pyrolysis often describes processes in which oils are preferred products (Mohan et al., 2006). Generally speaking, pyrolysis is the thermal process in the absence of oxygen to produce solid (char), liquid (tar), and gas (Demirbas, 2005), whose proportion is governed by feedstock properties and operating parameters (Mohan et al., 2006).

\footnotetext{
* Corresponding author. Tel.: +886 2 23625373; fax: +886223928830.

E-mail address: sllo@ntu.edu.tw (S.L. Lo).
}

Microwaves are a kind of electromagnetic wave, whose frequencies lie in between $300 \mathrm{MHz}$ and $300 \mathrm{GHz}$ by general definition. Not all materials can absorb microwaves. The materials can be classified into three types according to their interactions with microwave, i.e., conductors (reflective), insulators (transparent), and dielectrics (absorptive). Thus microwave heating is also referred to as dielectric heating (Jones et al., 2002). In conventional heating manner, heat is transferred into the material through convection, conduction, and radiation of heat from the surfaces of the material. On the contrary, microwave energy is delivered directly into materials through molecular interaction with the electromagnetic field. In heat transfer, energy is transferred due to thermal gradients by conventional heating, but microwave heating is the transfer of electromagnetic energy to thermal energy and is energy conversion, rather than heat transfer. This difference in the way energy is delivered can result in many potential advantages to using microwaves for processing of materials (Thostenson and Chou, 1999).

There are so many application accomplished by microwave technology, including drying, heating, synthesis, digestion, extraction, etc. This may be due to the rapid, uniform, and selective heating of microwave radiation, and there is no direct contact between the microwave source and the heated material. The microwave heating has been applied to pyrolysis of many kinds of feedstocks, including the oil-palm stone (Guo and Lua, 2000), oil shale (El Harfi et al., 2000), paper (Miura et al., 2001), plastics (Ludlow-Palafox and Chase, 2001), rock phosphate (Bilali et al., 2005), sewage sludge (Menendez et al., 2002; Dominguez et al., 2003), wood (Miura et al., 2004), and coffee hulls (Dominguez et al., 2007). Compared with the conventional pyrolysis conducted by electric 
furnace, the microwave pyrolysis produces more content of $\mathrm{H}_{2}$ and CO (Menendez et al., 2004), which is the so-called syngas. Besides, microwave pyrolysis generates less polycyclic aromatic hydrocarbons (PAHs), so it provides less hazardous compounds (Dominguez et al., 2003). However, the key effecting factors of these results and the possible application of the pyrolytic products are still ambiguous and need to be further explored.

In Taiwan, the annual average of rice production was ca. 1.6 million tonnes in 2001-2005 (Agriculture and Food Agency, COA, Executive Yuan, 2006). For every tonne of grain harvested, ca. 1.35 tonnes of rice straw remain in the field (Kadam et al., 2000). Therefore there is ca. 2.2 million tonnes of rice straw generated every year. Furthermore, to refer to the database from the Food and Agriculture Organization of the United Nations, the worldwide rice production is ca. 600 million tonnes every year (Food and Agriculture Organization, United Nations, 2007), so ca. 810 million tonnes of rice straw can be generated. This is really a large quantity of waste, or the source of resources and energy. Therefore, this study was aimed (1) to determine the key parameters affecting the microwave-induced pyrolysis, (2) to assess the characteristics and applicability of products, and (3) to evaluate the feasibility of total recovery of rice straw via microwave-induced pyrolysis.

\section{Methods}

\subsection{Materials}

The rice was planted in Pingtung, the southern Taiwan. After harvest, the residual rice straw was weathered for 10 days, till the constant moisture was reached. After shredding, the rice straw was sieved by $20 / 40$ mesh $(0.850 / 0.425 \mathrm{~mm}$ opening), to collect the designate sieved part as sample. The general characteristics and constituents of rice straw were analyzed and listed in Table 1. The proximate and elemental analyses were referred to ASTM Standard Test Method D 5142 and D 5291, respectively. The volatile content ( 72.20 wt.\%, dry basis) was much higher compared with ash and fixed carbon content. The molar ratio of $\mathrm{C}: \mathrm{H}: \mathrm{O}$ of ash-free rice straw was $1: 1.66: 0.78$ (6:9.96:4.67), which nearly matched the

Table 1

General characteristics and constituents of rice straw

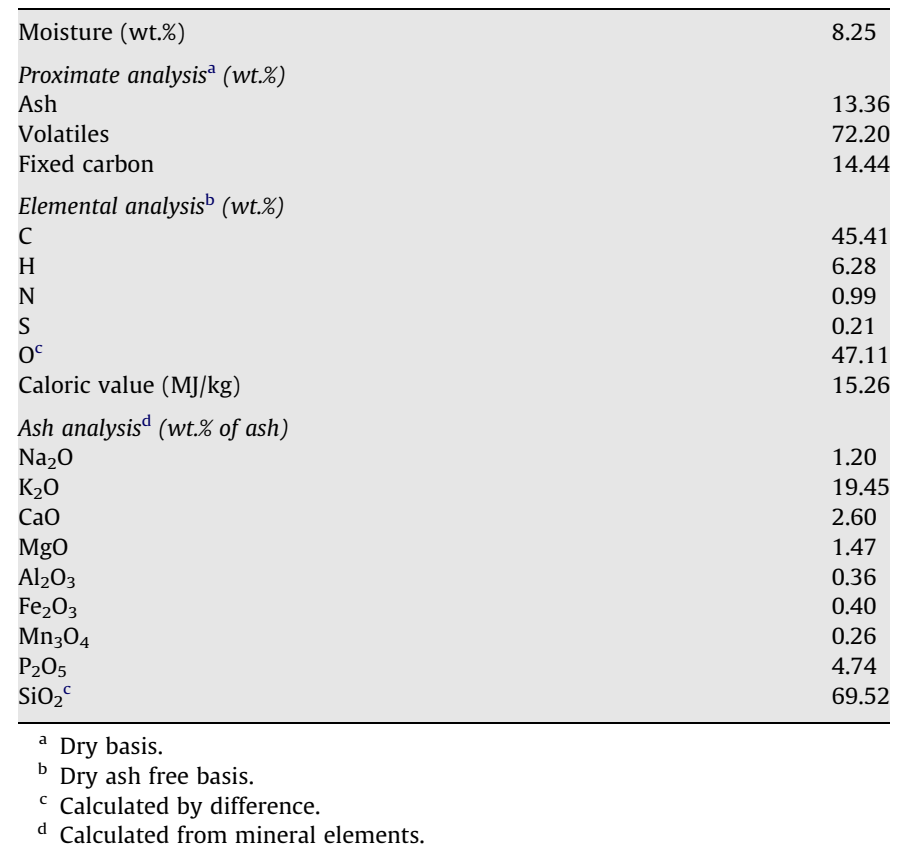

chemical formula of cellulose $\left(\mathrm{C}_{6} \mathrm{H}_{10} \mathrm{O}_{5}\right)_{n}$. To determine the hemicellulose, cellulose, and lignin contents in the rice straw, the thermal gravity analyses (TGA, Perkin-Elmer SDTA851) were also executed via ASTM Standard Test Method E 2402. We used the xylan to represent the hemicellulose, and the filter paper (Advantec) to represent the cellulose. According to the TGA results, the approximate compositions of hemicellulose, cellulose, and lignin in the rice straw were 30-35, 21-31, 4-19 wt.\%, respectively. The average gross caloric value was $15.26 \mathrm{MJ} / \mathrm{kg}$. The ash content of rice straw was relatively lower (13.36 wt.\%, dry basis). The mineral components in ash were analyzed by ICP-AES (Perkin-Elmer, Optima 2000 DV) via US EPA Method 3052 and 200.7, and the results were calculated to oxide-forms as listed in Table 1.

\subsection{Experimental device}

This study utilized the single-mode (focused) microwave device with $2.45 \mathrm{GHz}$ frequency. The maximal incident power of microwave generator was $2000 \mathrm{~W}$. Although the short circuit was set in the end of microwave pathway, there was still somewhat reflectional power could be detected during the experiments. To minimize the reflectional power and to maximize the working power into the sample, the three-stub tuner was used for adjustment. For the safety concern, the ambient radiation was always monitored, especially at the time of radiation beginning. The reflectional power was quenched by the setup of water load. The zone where pyrolytic reaction occurs was secluded by microwave cut-off shield. The sample holder ( $3 \mathrm{~cm}$ height, $4 \mathrm{~cm}$ OD) and reaction tube $(40 \mathrm{~cm}$ length, $5 \mathrm{~cm}$ OD) were both made of quartz. Both the ends of the quartz tube were screwed tight with o-ring and stainless steel sealer. The reaction temperature was hard to measure directly in microwave field because the thermocouple could be interfered by electromagnetic radiation. In this study, the thermocouple sensor was settled at the bottom of sample holder; therefore, the nearby temperature was adopted to express the relative thermal effect of various microwave powers. The vapor produced during experiments was immediately cooled by condenser. The condensable part of vapor was collected by tar collector, and the incondensable gas was also collected separately. For the purpose of expelling the air in the reactor quickly and/or maintaining vacuum circumstances in the whole system, a vacuum pump was also equipped.

\subsection{Microwave-induced pyrolysis procedure}

The shredded and sieved rice straw was taken by 3-5 g (precision to $0.1 \mathrm{mg}$ ) in the sample holder. After the sample was placed rightly in the pathway of microwave and the quartz tube was well sealed, a constant flow of carrier gas $\left(\mathrm{N}_{2}\right)$ was purged into the system with a flow rate of $50 \mathrm{~mL} / \mathrm{min}$. After the anoxic circumstances were reached under enough purging, the microwave generator was turned on and switched to the designate power. The practical working power was attained by the difference of incident power and reflectional power. During the proceeding of reaction, the reaction temperature was recorded with periodic time interval. The condenser was cooled by thermostat with a constant temperature of $4{ }^{\circ} \mathrm{C}$. After the arrival of designate reaction time, the microwave generator was turned off and the carrier gas was shut down, and then the tar and gas collectors were removed and sealed. After the solid residues were self-cooled down to close to $100^{\circ} \mathrm{C}$, they were removed and placed in the desiccator for few hours. The solid residues were weighed after reaching the room temperature.

\subsection{Characterization of solid residues}

The caloric analysis of rice straw and pyrolyzed products was carried out by CAL2k ECO calorimeter. The elemental analysis 


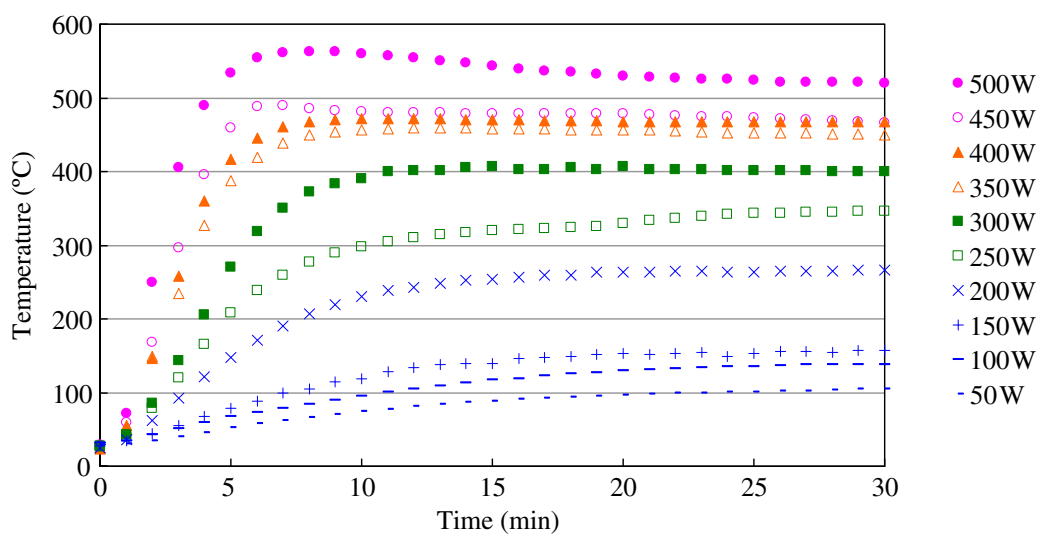

Fig. 1. The temperature profiles under different microwave power.

was executed by Perkin-Elmer 2400 series II CHNS/O analyzer. Before the mineral analysis achieved by Perkin-Elmer Optima 2000 DV ICP-AES, the sample was acid-digested by CEM MARS-5 microwave system. The BET analysis was carried out by Micromeritics ASAP 2010. The zeta potential of the solid residues in aqueous solution at $\mathrm{pH}$ values between 2 and 11 was measured using a laser doppler electrophoretic light-scattering apparatus (Malvern Instrument Zetasizer 2000). Triplicate measurements were made in crossed-beam mode with a $30 \mathrm{~s}$ count time, an applied voltage of $150 \mathrm{~V}$, and a modulator frequency of $1000 \mathrm{~Hz}$.

\section{5. $\mathrm{Cu}^{2+}$ adsorption analysis}

Batch experiments concerning $\mathrm{Cu}^{2+}$ adsorption onto $0.05 \mathrm{~g}$ solid residues produced from $500 \mathrm{~W}$ microwave-induced pyrolysis were conducted in $50 \mathrm{~mL}$ polypropylene bottles with caps. After adjustment to the desired $\mathrm{pH}$ using $\mathrm{NaOH}$ and $\mathrm{HNO}_{3}$ solutions, all experiments were isothermal of $25^{\circ} \mathrm{C}$, with shaking at $150 \mathrm{rpm}$. Since preliminary kinetic experiments suggested that pseudo-equilibrium was reached within $24 \mathrm{~h}, 24 \mathrm{~h}$ was selected as the reaction time for the equilibrium experiments. After the reaction, the suspension was centrifuged (Kubota 6800) at 10,000 rpm for $15 \mathrm{~min}$ and the supernatant was passed through a $0.2-\mu \mathrm{m}$ membrane filter to analyze the soluble $\mathrm{Cu}^{2+}$ by an ICP-AES (Perkin-Elmer, Optima 2000 DV).

\subsection{Analyses of gaseous and liquid products}

The analysis of gaseous product was executed by Perkin-Elmer AutoSystem XL gas chromatography/thermal conductivity detector (GC/TCD) with the SUPELCO Carboxen-1010 PLOT fused silica capillary column $(30 \mathrm{~m} \times 0.53 \mathrm{~mm})$. The temperatures of injector, oven, and detector were 100,90 , and $150^{\circ} \mathrm{C}$, respectively. The flow rate of carrier gas was $15 \mathrm{~mL} / \mathrm{min}$ without split. The liquid product was analyzed by Perkin-Elmer TurboMass Gold gas chromatography/mass spectrometry (GC/MS) with the SUPELCO Equity-5 fused silica capillary column $(30 \mathrm{~m} \times 0.25 \mathrm{~mm} \times 0.25 \mu \mathrm{m})$. The initial temperature of oven was $45^{\circ} \mathrm{C}$ held for $3 \mathrm{~min}$, followed with a program from $45^{\circ} \mathrm{C}$ to $300{ }^{\circ} \mathrm{C}$ by the rate of $5{ }^{\circ} \mathrm{C} / \mathrm{min}$, and then held for $5 \mathrm{~min}$. The flow rate of carrier gas was $1.5 \mathrm{~mL} / \mathrm{min}$ with a split of $20 \mathrm{~mL} / \mathrm{min}$

\section{Results and discussion}

\subsection{Temperature profiles}

Under different microwave power, the temperature profiles of pyrolytic reaction are shown in Fig. 1 . All the samples were ca.
$3 \mathrm{~g}$, and the particle size was between 20/40 mesh $(0.425$ $0.850 \mathrm{~mm}$ ). During the time of $30 \mathrm{~min}$ of microwave radiation, the reaction temperatures slowly increased, and the maximal reaction temperatures were only $105-158{ }^{\circ} \mathrm{C}$, under the microwave power of 50-150 W. These conditions only offered the desiccation and slight pyrolysis of samples. For the microwave power of $200 \mathrm{~W}$ and upward, the reaction temperatures increased much faster. And for the microwave power of upwards of $300 \mathrm{~W}$, the maximal reaction temperatures were reached in $10 \mathrm{~min}$ or less. Under the microwave power of 450 and $500 \mathrm{~W}$, the maximal reaction temperature was reached in 7-8 min, and then slowly decreased till the microwave radiation was stopped. These phenomena show that higher the microwave power, higher the heating rate and the maximal reaction temperature, as presented in Table 2.

The relationships between the microwave power $(P)$ with heating rate $(\mathrm{d} T / \mathrm{d} t)$ and maximal temperature $\left(T_{\max }\right)$ were also determined. The linear regression of microwave power with heating rate is $\mathrm{d} T / \mathrm{d} t=0.32 P-27.6$, which indicates that to start an apparent rise in temperature, sufficient power input is needed. To set $\mathrm{d} T /$ $\mathrm{d} t=0$, and $P$ will be $86 \mathrm{~W}$, which means the minimal microwave power to raise the temperature. Although there was still a rise in temperature by microwave power of $50 \mathrm{~W}$, this phenomenon should be due to the vaporization of water content by such a low microwave power. The linear regression of microwave power with maximal temperature is $T_{\max }=1.07 P+47.2$, whose intercept is somewhat close to the average of room temperature. These relationships may be some proofs of reliability of the temperature measurements and experimental results.

These temperature profiles also showed that there was no need of microwave receptor to promote the pyrolysis of rice straw, although the rice straw was not dielectric. This may attribute to the satisfactory performance of single-mode microwave device. The radiant energy can be highly focused to create a hot spot inside

Table 2

Heating rate and maximal temperature under different microwave power

\begin{tabular}{lcl}
\hline MW power $(\mathrm{W})$ & ${\text { Heating } \operatorname{rate}^{\mathrm{a}}\left({ }^{\circ} \mathrm{C} / \mathrm{min}\right)}$ & Max. temp. $\left({ }^{\circ} \mathrm{C}\right)$ \\
\hline 50 & 5 & 105 \\
100 & 8 & 138 \\
150 & 11 & 158 \\
200 & 29 & 266 \\
250 & 42 & 346 \\
300 & 55 & 407 \\
350 & 92 & 459 \\
400 & 102 & 472 \\
450 & 114 & 489 \\
500 & 141 & 563 \\
\hline
\end{tabular}

${ }^{\text {a }}$ Calculated from the slope of linear regression of temperatures from 1 st to 4 th $\min$. 
the rice straw sample. As long as the microwave power was higher than $86 \mathrm{~W}$ as above mentioned, there would be sufficient energy to pyrolyze the sample. Moreover, some char was generated during the beginning of reaction, and then it could become an additional microwave receptor to further promote the reaction. The char has good dielectric property and is commonly utilized as a microwave receptor (Menendez et al., 2002; Dominguez et al., 2007).

\subsection{Mass reduction}

The experimental results indicated that there was the higher mass reduction ratio for the higher microwave power, meanwhile the higher reaction temperature (Fig. 1). For the microwave power of $200 \mathrm{~W}$, the mass reduction ratio was just ca. $60 \mathrm{wt}$.\%. This percentage showed that there was still some volatile content remained. Once the microwave power was $300 \mathrm{~W}$ and upward, almost all of the volatile content was pyrolyzed. Furthermore, some fixed carbon or even ash content was reduced under the higher microwave power. Till the microwave power of $500 \mathrm{~W}$, the mass reduction ratio was ca. $80 \mathrm{wt} . \%$, and the residual ratio was much lower than the sum of fixed carbon and ash content (ca. 26 wt.\%).

\subsection{Particle size effect}

To promote the performance of microwave pyrolysis, the particle size effect was also considered. Fig. 2 shows the temperature profiles of two particle sizes, $20 / 40$ mesh $(0.425-0.850 \mathrm{~mm})$ and $<40$ mesh $(0.425 \mathrm{~mm})$, under the microwave power of 200 and $300 \mathrm{~W}$. After the particle size was shred to further smaller, both the heating rate and the maximal reaction temperature were increased. The mass reduction ratios are also enhanced, from $60 \%$ to $70 \%$ for $200 \mathrm{~W}$ and from $73 \%$ to $75 \%$ for $300 \mathrm{~W}$, respectively. These results may be due to that once the particle size was reduced, the higher bulk density and intraparticular contact area promoted the heat transfer inside the feedstock. The microwave energy might only focus on one hotspot, so better heat transfer would accelerate the entire pyrolytic reaction. Therefore, the heating rate, maximal reaction temperature, and mass reduction ratio were all increased. For smaller particle size, the satisfactory microwave power could be lowered. However, the practical application and limitation need to be further concerned.

\subsection{Characteristics of solid residues}

\subsubsection{Caloric analysis}

The caloric value of solid residues under various microwave power is shown in Fig. 3. When the microwave power was 200$350 \mathrm{~W}$, the gross caloric values of solid residues ranged from 18.51 to $19.66 \mathrm{MJ} / \mathrm{kg}$, which was much higher than that of rice

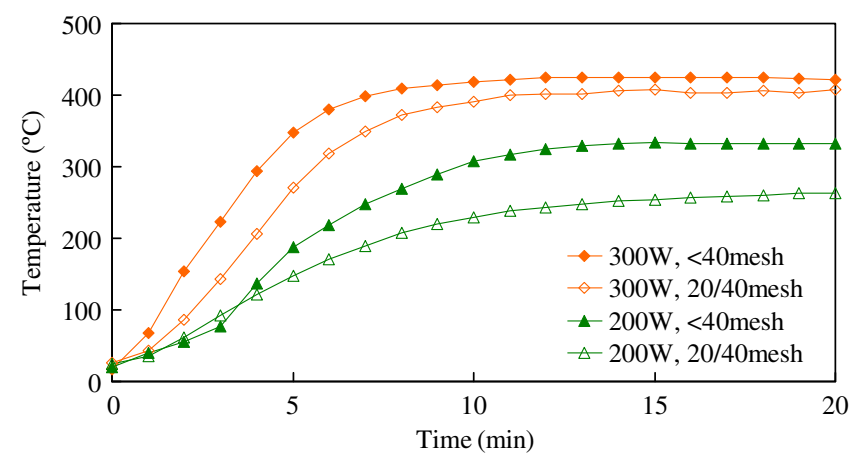

Fig. 2. The particle size effect on reaction temperature.

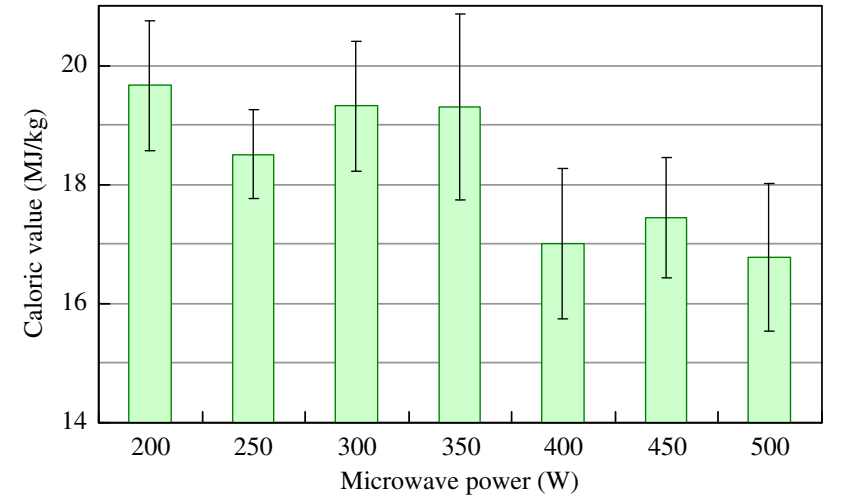

Fig. 3. The caloric values of solid residues under different microwave power.

straw $(15.26 \mathrm{MJ} / \mathrm{kg})$. This might be due to that the volatile content was removed during pyrolytic process, and meanwhile the fixed carbon content with high caloric value became the major part. However, under 400-500 W microwave power, the caloric values of solid residues decreased to $16.78-17.44 \mathrm{MJ} / \mathrm{kg}$. This might imply that if the microwave power is high enough, some of the fixed carbon content can be also pyrolyzed. Therefore, there will be an apparent loss of fixed carbon content if the microwave power is higher than $400 \mathrm{~W}$, which also means the reaction temperature of ca. $470{ }^{\circ} \mathrm{C}$ above.

\subsubsection{Elemental analysis}

The solid residues produced from microwave pyrolysis were also analyzed for its elemental composition. To take an example of solid residues produced by $300 \mathrm{~W}$ microwave radiations, the results of elemental analysis are listed in Table 3 . The percentages (dry ash free basis) of $\mathrm{C}, \mathrm{H}, \mathrm{N}$, and $\mathrm{S}$ in solid residues were 62.21 wt.\%, 3.52 wt.\%, 1.27 wt.\%, and 0.72 wt.\%, respectively. The percentage of $\mathrm{O}$ was $32.28 \mathrm{wt} . \%$ calculated by difference. The ashfree $\mathrm{C}: \mathrm{H}: \mathrm{O}$ molar ratio of solid residues was 1:0.68:0.39, which was totally different from the proportion of original rice straw. This might mean that the $300 \mathrm{~W}$ microwave radiation is sufficient for the reaction of cellulosic content. Hence the cellulosic content was removed, and the molar ratio was also changed. The average reduction ratios of $\mathrm{C}, \mathrm{H}, \mathrm{N}$, and $\mathrm{S}$ were $82.23 \mathrm{wt} . \%, 91.79 \mathrm{wt} \%$, 85.01 wt.\%, and 62.89 wt.\%, respectively. The unreacted part of C and $\mathrm{H}$ might be derived from the resistant hydrocarbons (e.g., lignin), and this need to be further determined.

\subsubsection{Mineral analysis}

For the mineral analysis of solid residues produced by $300 \mathrm{~W}$ microwave radiations, the result of primary minerals is shown in

Table 3

Elemental analysis of solid residues ${ }^{\mathrm{a}}$

\begin{tabular}{lccll}
\hline & $\begin{array}{l}\text { Dry basis } \\
\text { (wt.\%) }\end{array}$ & $\begin{array}{l}\text { Dry ash free } \\
\text { basis (wt.\%) }\end{array}$ & $\begin{array}{l}\text { Molar } \\
\text { ratio }\end{array}$ & $\begin{array}{l}\text { Reduction ratio } \\
\text { (wt.\%) }\end{array}$ \\
\hline Elemental analysis & & & & \\
$\mathrm{C}$ & 29.86 & 62.21 & 1.00 & 82.23 \\
$\mathrm{H}$ & 1.69 & 3.52 & 0.68 & 91.79 \\
$\mathrm{~N}$ & 0.62 & 1.27 & 0.02 & 85.01 \\
$\mathrm{~S}$ & 0.34 & 0.72 & 0.00 & 62.89 \\
$\mathrm{O}^{\mathrm{b}}$ & - & 32.28 & 0.39 & - \\
Proximate analysis & & & & \\
Ash & 46.21 & & & \\
Volatiles & 8.95 & & & \\
Fixed carbon & 44.84 & & & \\
\hline
\end{tabular}

a All were produced under microwave power of $300 \mathrm{~W}$.

b Calculated by difference. 
Table 4

Mineral analysis of solid residues ${ }^{\mathrm{a}}$

\begin{tabular}{ccccccccc}
\hline & $\mathrm{Na}$ & $\mathrm{K}$ & $\mathrm{Ca}$ & $\mathrm{Mg}$ & $\mathrm{Al}$ & $\mathrm{Fe}$ & $\mathrm{Mn}$ & $\mathrm{P}$ \\
\hline $\begin{array}{c}\text { Percentage } \\
\begin{array}{c}\text { (wt.\%) } \\
\text { (wt. }\end{array}\end{array}$ & 0.35 & 6.73 & 0.79 & 0.34 & 0.06 & 0.10 & 0.07 & 0.85 \\
$\begin{array}{c}\text { Recovery } \\
\text { (wt.\%) }\end{array}$ & 85 & 91 & 93 & 84 & 70 & 80 & 86 & 89 \\
\hline
\end{tabular}

a All were produced under microwave power of $300 \mathrm{~W}$.

b Represents the average percentages of mineral elements in solid residues.

c Means the ratios of the quantity of mineral elements in solid residues to in original rice straw.

Table 4. The ratios of mineral elements in solid residues to in original rice straw were also calculated to determine the recovery. Generally, most of the minerals were not removed or even reacted, and the recoveries were 70-93 wt.\%, among which the recovery of $\mathrm{Al}$ was lowest and the recovery of Ca was highest.

\subsubsection{Specific surface area analysis}

The solid residues produced by microwave pyrolysis of 300 , 400 , and $500 \mathrm{~W}$ power was tested for surface area analysis, as presented in Table 5 . The BET surface area $\left(S_{\mathrm{BET}}\right)$, Langmuir surface area $\left(S_{\mathrm{L}}\right)$, and mesopore surface area $\left(S_{\text {mesopore }}\right)$ were $165.74-$ $274.49,233.88-372.11$, and $130.93-196.10 \mathrm{~m}^{2} / \mathrm{g}$, respectively. For the change of microwave power from 300 to $500 \mathrm{~W}$, the specific surface area could be increased by ca. 1.6 times. There was more specific surface area with higher microwave power, and so as the tendencies of total pore volume $\left(V_{\mathrm{T}}\right)$ and mesopore volume $\left(V_{\text {mesopore }}\right)$. The average pore diameter $\left(D_{\text {ave }}\right.$, calculated by $\left.4 V_{\mathrm{T}} / S_{\mathrm{BET}}\right)$ was 24-25 $\AA$, so there was almost no difference between diameters under 300-500 W microwave radiations. Therefore, the high specific surface area of solid residues produced by microwave pyrolysis might be seen as a kind of adsorbent.

\subsubsection{Zeta potential analysis}

The results of zeta potential analyses of solid residues suspension indicated that the solid residues possessed net negativecharged property in most $\mathrm{pH}$ range, especially under the neutral and basic circumstances ( $\mathrm{pH} 3-11)$. The surface potential decreased with increasing $\mathrm{pH}$ value, and reached to ca. $-30 \mathrm{mV}$ under $\mathrm{pH} 9-11$. The point of zero charge lay in between $\mathrm{pH} 3$ and 4 . This surface electric behavior of solid residues was similar to that of $\mathrm{SiO}_{2}$ suspension. This phenomenon may attribute to that most of the organic parts were pyrolyzed into gaseous and liquid products, hence the mineral ingredients, especially $\mathrm{SiO}_{2}$ became the main components in the solid residues. This may also imply that $\mathrm{SiO}_{2}$ took a major part in the ash content of rice straw. Therefore, the surface properties of solid residues mainly behaved as the $\mathrm{SiO}_{2}$ particles.

\subsubsection{The $\mathrm{Cu}^{2+}$ adsorption of solid residues}

The $\mathrm{Cu}^{2+}$ adsorption done by solid residues was tested under the $\mathrm{pH} 3$ and $\mathrm{pH} 5$ circumstances, as presented in Fig. 4. We chose

\section{Table 5}

Specific surface area analysis of solid residues ${ }^{a}$

\begin{tabular}{lllllll}
\hline $\begin{array}{l}\text { Microwave } \\
\text { power }(\mathrm{W})\end{array}$ & $\begin{array}{l}S_{\mathrm{BET}} \\
\left(\mathrm{m}^{2} / \mathrm{g}\right)\end{array}$ & $\begin{array}{l}S_{\mathrm{L}} \\
\left(\mathrm{m}^{2} / \mathrm{g}\right)\end{array}$ & $\begin{array}{l}S_{\text {mesopore }} \\
\left(\mathrm{m}^{2} / \mathrm{g}\right)\end{array}$ & $\begin{array}{l}V_{\mathrm{T}} \\
\left(\mathrm{cm}^{3} / \mathrm{g}\right)\end{array}$ & $\begin{array}{l}V_{\text {mesopore }} \\
\left(\mathrm{cm}^{3} / \mathrm{g}\right)\end{array}$ & $\begin{array}{l}D_{\text {ave }} \\
(\AA)\end{array}$ \\
\hline 300 & 165.74 & 233.88 & 130.93 & 0.10 & 0.07 & 24.66 \\
400 & 240.30 & 324.41 & 182.42 & 0.15 & 0.09 & 24.25 \\
500 & 274.49 & 372.11 & 196.10 & 0.17 & 0.09 & 24.91 \\
\hline
\end{tabular}

a Analysis items are $S_{\mathrm{BET}}$ : BET surface area, $S_{\mathrm{L}}$ : Langmuir surface area, $S_{\text {mesopore }}$ mesopore surface area, $V_{\mathrm{T}}$ : total pore volume, $V_{\text {mesopore }}$ : mesopore volume, and $D_{\text {ave }}$ : average pore diameter.

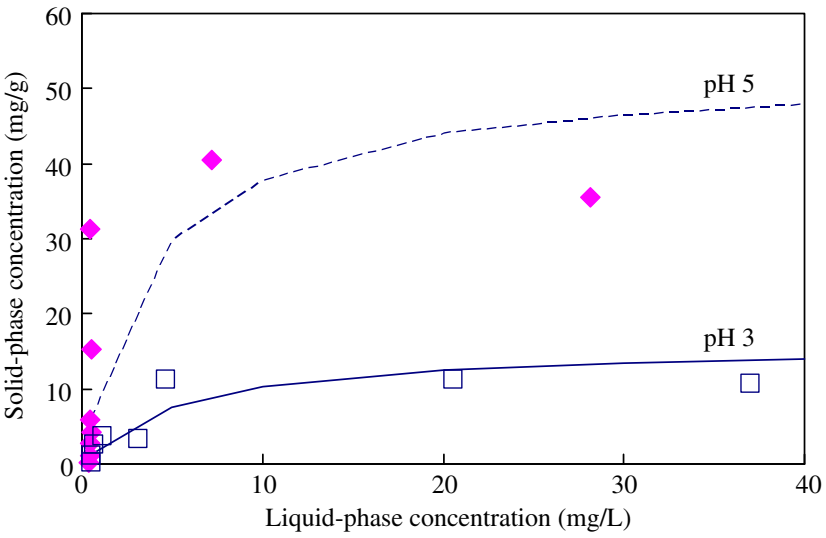

Fig. 4. The $\mathrm{Cu}^{2+}$ adsorption of solid residues under $\mathrm{pH} 3$ and $\mathrm{pH} 5$ circumstances.

Table 6

The $\mathrm{Cu}^{2+}$ adsorption isotherms of solid residues

\begin{tabular}{llllllll} 
& \multicolumn{3}{ll}{ Langmuir isotherm $^{\mathrm{a}}$} & & & \multicolumn{3}{l}{ Freundlich isotherm $^{\mathrm{b}}$} \\
\cline { 2 - 3 } & $q_{\mathrm{m}}$ & $K_{\mathrm{L}}$ & $r_{1}{ }^{\mathrm{c}}$ & & $K_{\mathrm{F}}$ & $n_{\mathrm{F}}$ & $r_{2}{ }^{\mathrm{c}}$ \\
\hline pH 3 & 16.00 & 0.18 & 0.90 & & 8.92 & 2.08 & 0.88 \\
pH 5 & 52.36 & 0.26 & 0.57 & & 11.26 & 2.34 & 0.65 \\
\hline
\end{tabular}

a Langmuir isotherm: $q=q_{\mathrm{m}} K_{\mathrm{L}} c /\left(1+K_{\mathrm{L}} c\right)$

b Freundlich isotherm: $q=K_{\mathrm{F}} \cdot c^{\wedge}\left(1 / n_{\mathrm{F}}\right)$

c $r_{1}$ and $r_{2}$ represent the correlation coefficients of $1 / q$ versus $1 / c$ for Langmuir isotherm, and $\log q$ versus $\log c$ for Freundlich isotherm, respectively.

this acidic circumstances to prevent the interference from the precipitation of $\mathrm{Cu}(\mathrm{OH})_{2}$. The results showed that even in the acidic solution, the solid residues were able to adsorb $\mathrm{Cu}^{2+}$. Under $\mathrm{pH} 3$, the maximal $\mathrm{Cu}^{2+}$ removal percentage was $79 \%$ via the initial $\mathrm{Cu}^{2+}$ concentration of $3.18 \mathrm{mg} / \mathrm{L}$, and then decreased for the higher concentrations. In the $\mathrm{pH} 5$ solutions, the $\mathrm{Cu}^{2+}$ removal rate can be higher than $90 \%$ for the initial $\mathrm{Cu}^{2+}$ concentrations of $6.35-31.77 \mathrm{mg} / \mathrm{L}$. This result may be due to that the surfaces of solid residues tend to be more negative charged at higher $\mathrm{pH}$. Additionally, to refer to the result of zeta potential analysis, $\mathrm{Cu}^{2+}$ can be adsorbed over wide $\mathrm{pH}$ range even as low as $\mathrm{pH} 3$, and as high as $\mathrm{pH}$ 11. The phenomena imply that the solid residues can be successfully served as an adsorbent for water or wastewater treatment. The analyses of Langmuir and Freundlich isotherm of $\mathrm{Cu}^{2+}$ adsorption by solid residues were also accomplished, as shown in Table 6. The simulated values from Langmuir isotherm are also shown in Fig. 4; the solid and dash lines represent the $\mathrm{pH} 3$ and pH 5 simulations, respectively. Under $\mathrm{pH} 3$ circumstances, the adsorption behavior was much more matched for both Langmuir and Freundlich isotherms than under pH 5 circumstances. Therefore according to the Langmuir isotherm result, the single-layer adsorption isotherm was more approached under less $\mathrm{Cu}^{2+}$ adsorption quantity.

\subsection{The analysis of gaseous product}

The composition of gaseous product produced from $300 \mathrm{~W}$ microwave-induced pyrolysis is shown in Fig. 5. The original percentages mean the test values via the sampling bag, and $\mathrm{H}_{2}, \mathrm{CO}_{2}$, $\mathrm{CO}, \mathrm{CH}_{4}$ contents were $44,13,10,8$ vol.\%, respectively. However, inside the sampling bag, there was still quite an amount of carrier gas. The modified values which represent the composition of gaseous product with the further deduction of the volume of carrier gas, can be seen as the true composition of gaseous product. Hence, the modified percentages of $\mathrm{H}_{2}, \mathrm{CO}_{2}, \mathrm{CO}, \mathrm{CH}_{4}$ were $55,17,13$, 


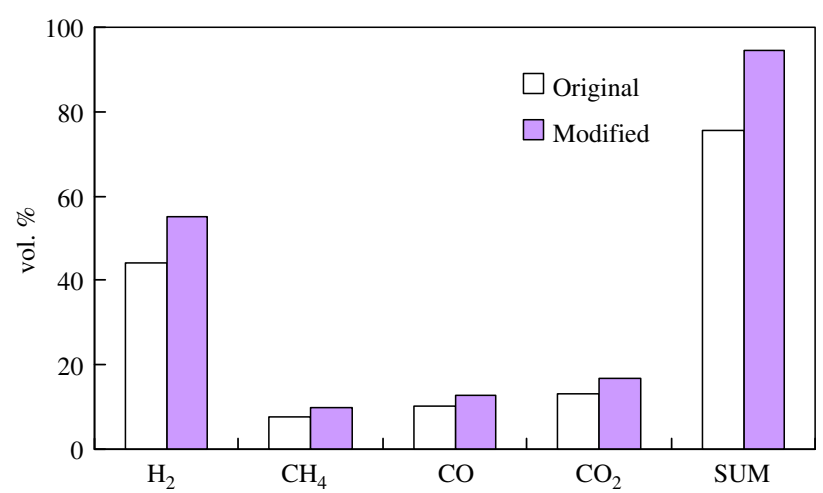

Fig. 5. The composition of gaseous product produced from $300 \mathrm{~W}$ microwave-induced pyrolysis.

Table 7

The GC/MS analysis of liquid product

\begin{tabular}{|c|c|c|}
\hline Compound & $m / z$ & Relative percentage (area\%) \\
\hline \multicolumn{3}{|l|}{ Alkanes } \\
\hline Dodecane & 170 & 1.73 \\
\hline Tridecane & 184 & 0.85 \\
\hline Tetradecane & 198 & 3.62 \\
\hline Pentadecane & 212 & 0.17 \\
\hline Hexadecane & 226 & 1.76 \\
\hline Heptadecane & 240 & 0.27 \\
\hline Octadecane & 254 & 0.62 \\
\hline Nonadecane & 268 & 0.24 \\
\hline Eicosane & 282 & 0.22 \\
\hline Heneicosane & 296 & 0.20 \\
\hline Docosane & 310 & 1.68 \\
\hline Tricosane & 324 & 1.10 \\
\hline Tetracosane & 338 & 1.67 \\
\hline Pentacosane & 352 & 1.88 \\
\hline Hexacosane & 366 & 2.55 \\
\hline Heptacosane & 380 & 3.79 \\
\hline Octacosane & 394 & 5.75 \\
\hline Nonacosane & 408 & 6.61 \\
\hline Triacontane & 422 & 4.95 \\
\hline Hentriacontane & 436 & 2.81 \\
\hline \multirow[t]{2}{*}{ Dotriacontane } & 450 & 1.23 \\
\hline & Sum & 43.68 \\
\hline \multicolumn{3}{|l|}{ Polars } \\
\hline Phenol & 94 & 9.37 \\
\hline Methylphenol & 108 & 11.18 \\
\hline Dimethylphenol & 122 & 1.73 \\
\hline Ethylphenol & 122 & 2.46 \\
\hline Trimethylphenol & 136 & 0.41 \\
\hline \multirow[t]{2}{*}{ Trimethylbenzenediol } & 152 & 0.70 \\
\hline & Sum & 25.84 \\
\hline \multicolumn{3}{|c|}{ Polycyclic aromatic hydrocarbons } \\
\hline Naphthalene & 128 & 3.72 \\
\hline Methylnaphthalene & 142 & 0.96 \\
\hline Dimethylnaphthalene & 156 & 0.33 \\
\hline Acenaphthylene & 152 & 1.22 \\
\hline Fluorene & 166 & 0.96 \\
\hline \multirow[t]{2}{*}{ Anthracene } & 178 & 1.75 \\
\hline & Sum & 8.94 \\
\hline
\end{tabular}

10 vol.\%, respectively. The $\mathrm{H}_{2}$ content produced from traditional pyrolysis was ca. 25 vol.\% (Chen et al., 2003), lower than the result in this study. This shows that microwave-induced pyrolysis of biomass waste might have the potential to produce the $\mathrm{H}_{2}$-rich fuel gas. Furthermore, to approximately calculate the caloric value of the gaseous product, the each higher heating value (HHV) of $\mathrm{H}_{2}, \mathrm{CO}$, and $\mathrm{CH}_{4}$ were applied, and the ideal gas law was also utilized. The calculated caloric value of the gaseous product was $11.54 \mathrm{MJ} / \mathrm{Nm}^{3}$, which has been higher than the values (4-7 MJ/ $\mathrm{Nm}^{3}$ ) from the gasification (Rao et al., 2004; Bebar et al., 2005).
The weight yield of gaseous product was calculated via the ideal gas law. The relative percentages of gaseous, solid and liquid products were $49.37,28.07$, and $22.56 \mathrm{wt}$.\%, respectively. The yield of liquid product was calculated by difference owing to the difficulty of recovery. Therefore, there was almost half of rice straw sample pyrolyzed into gaseous product. Compared with the traditional pyrolysis (Bridgwater, 2003; Chen et al., 2003), the yield of gaseous product from microwave-induced pyrolysis was higher for $2-7 \%$ or even much above.

\subsection{The analysis of liquid product}

The liquid product generated from microwave-induced pyrolysis $(300 \mathrm{~W})$ was extracted by dichloromethane and then analyzed by GC/MS. A semi-quantitative analysis was accomplished by means of the relative percentage of chromatographic area of each compound, as shown in Table 7. The major compounds in the liquid product can be divided into three groups: (1) alkanes, from $\mathrm{C} 12$ to $\mathrm{C} 32$; (2) polars, including phenol and its derivatives; and (3) polycyclic aromatic hydrocarbons (PAHs), 2-3 rings and their derivatives. The percentage of alkanes, polars, and PAHs were $43.68,25.84$, and 8.94 area\%, respectively. Therefore, the composition of liquid product was highly alkylated and oxygenated, and the hazardous PAHs content was lesser. Moreover, the commonly-used PAHs toxicity indicators and International Agency for Research on Cancer (IARC) Group 2A-probable human carcinogens, including benz[a]anthracene, benzo[a]pyrene, and dibenz[a,h]anthracene (Tsai et al., 2007), were not detected in the liquid product, so the harmful property of liquid product might be less concerned. Since the composition of liquid product is so complicated, further refining will be necessary for practical utility.

\section{Conclusions}

The microwave power and particle size of feedstock were both key parameters affecting the performance of microwave-induced pyrolysis. For a certain outcome, the less microwave power will be satisfactory if the particles get smaller. After the pyrolysis of rice straw, three-phase products were generated and collected separately. The adsorption-related analyses of solid residues had shown the potential for the application in the removal of metallic contaminants. About half of rice straw sample was transformed into $\mathrm{H}_{2}$ rich fuel gas, whose $\mathrm{H}_{2}, \mathrm{CO}_{2}, \mathrm{CO}, \mathrm{CH}_{4}$ percentages were 55,17 , 13,10 vol.\%, respectively. The condensable part of product was highly alkylated and oxygenated, and the harmful PAHs content was quite less. Therefore, the authors inferred that total recovery of resources and energy from biomass waste would not be just a fantasy, by the utilization of microwave-induced pyrolysis. Nevertheless, the feasibility and practicability of this technology still need to be further researched.

\section{Acknowledgements}

The authors are grateful to the National Science Council, Taiwan for the financial support (Contract No. NSC 96-2218-E-002-004).

\section{References}

Agriculture and Food Agency, COA, Executive Yuan, 2006. Yearly Report of Taiwan's Agriculture, Taipei, Taiwan.

Bebar, L., Stehlik, P., Havlen, L., Oral, J., 2005. Analysis of using gasification and incineration for thermal processing of wastes. Appl. Therm. Eng. 25, 1045-1055.

Bilali, L., Benchanaa, M., El harfi, K., Mokhlisse, A., Outzourhit, A., 2005. A detailed study of the microwave pyrolysis of the Moroccan (Youssoufia) rock phosphate. J. Anal. Appl. Pyrol. 73, 1-15.

Bridgwater, A.V., Meier, D., Radlein, D., 1999. An overview of fast pyrolysis of biomass. Org. Geochem. 30, 1479-1493. 
Bridgwater, A.V., 2003. Renewable fuels and chemicals by thermal processing of biomass. Chem. Eng. J. 91, 87-102.

Bridgwater, T., 2006. Biomass for energy. J. Sci. Food Agric. 86, 1755-1768.

Chen, G., Andries, J., Spliethoff, H., Leung, D.Y.C., 2003. Experimental investigation of biomass waste (rice straw, cotton stalk, and pine sawdust) pyrolysis characteristics. Energy Sources 25, 331-337.

Demirbas, A., 2005. Pyrolysis of ground beech wood in irregular heating rate conditions. J. Anal. Appl. Pyrol. 73, 39-43.

Dominguez, A., Menendez, J.A., Inguanzo, M., Bernad, P.L., Pis, J.J., 2003. Gas chromatographic-mass spectrometric study of the oil fractions produced by microwave-assisted pyrolysis of different sewage sludges. J. Chromatogr., A 1012, 193-206.

Dominguez, A., Menendez, J.A., Fernandez, Y., Pis, J.J, 2007. Evidence of selfgasification during the microwave-induced pyrolysis of coffee hulls. Energy Fuels 21, 373-378.

El Harfi, K., Mokhlisse, A., Chanaa, M.B., Outzourhit, A., 2000. Pyrolysis of the Moroccan (Tarfaya) oil shales under microwave irradiation. Fuel 79, 733-742.

Food and Agriculture Organization, United Nations, 2007. FAOSTAT. <http:// faostat.fao.org/>.

Guo, J., Lua, A.C., 2000. Preparation of activated carbons from oil-palm-stone chars by microwave-induced carbon dioxide activation. Carbon 38, 1985-1993.

Jones, D.A., Lelyveld, T.P., Mavrofidis, S.D., Kingman, S.W., Miles, N.J., 2002. Microwave heating applications in environmental engineering-a review. Resour. Conserv. Recycl. 34, 75-90.
Kadam, K.L., Forrest, L.H., Jacobson, W.A., 2000. Rice straw as a lignocellulosic resource: collection, processing, transportation, and environmental aspects. Biomass Bioenergy 18, 369-389.

Ludlow-Palafox, C., Chase, H.A., 2001. Microwave-induced pyrolysis of plastic wastes. Ind. Eng. Chem. Res. 40, 4749-4756.

Menendez, J.A., Inguanzo, M., Pis, J.J., 2002. Microwave-induced pyrolysis of sewage sludge. Water Res. 36, 3261-3264.

Menendez, J.A., Dominguez, A., Inguanzo, M., Pis, J.J., 2004. Microwave pyrolysis of sewage sludge: analysis of the gas fraction. J. Anal. Appl. Pyrol. 71, 657-667.

Miura, M., Kaga, H., Yoshida, T., Ando, K., 2001. Microwave pyrolysis of cellulosic materials for the production of anhydrosugars. J. Wood Sci. 47, 502-506.

Miura, M., Kaga, H., Sakurai, A., Kakuchi, T., Takahashi, K., 2004. Rapid pyrolysis of wood block by microwave heating. J. Anal. Appl. Pyrol. 71, 187-199.

Mohan, D., Pittman, C.U., Steele, P.H., 2006. Pyrolysis of wood/biomass for bio-oil: a critical review. Energy Fuels 20, 848-889.

Rao, M.S., Singh, S.P., Sodha, M.S., Dubey, A.K., Shyam, M., 2004. Stoichiometric, mass, energy and exergy balance analysis of countercurrent fixed-bed gasification of post-consumer residues. Biomass Bioenergy 27, 155-171.

Thostenson, E.T., Chou, T.W., 1999. Microwave processing: fundamentals and applications. Compos. Part A-Appl. Sci. Manuf. 30, 1055-1071.

Tsai, W.T., Mi, H.H., Chang, Y.M., Yang, S.Y., Chang, J.H., 2007. Polycyclic aromatic hydrocarbons (PAHs) in bio-crudes from induction-heating pyrolysis of biomass wastes. Bioresource Technol. 98, 1133-1137. 